Review

\title{
Are geopolymers more suitable than Portland cement to produce high volume recycled aggregates HPC?
}

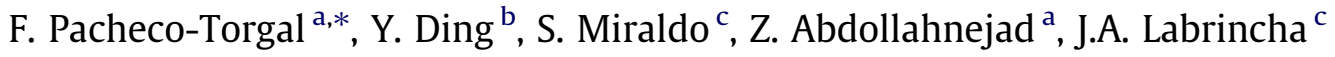 \\ ${ }^{a}$ University of Minho, C-TAC Research Centre, Guimarães, Portugal \\ ${ }^{\mathrm{b}}$ Dalian University of Technology, State Key Laboratory of Coastal and Offshore Engineering, Dalian, China \\ ${ }^{\mathrm{c}}$ University of Aveiro, CICECO, Aveiro, Portugal
}

\section{H I G H L I G H T S}

- Portland cement is unsuitable to produce HPC with a high volume of recycled aggregates.

- Recycled aggregates have impurities that can be deleterious for Portland cement concrete.

- Geopolymers may have the potential to reuse high volume of recycled aggregates in HPC.

\section{A R T I C L E I N F O}

\section{Article history:}

Received 11 May 2012

Accepted 8 July 2012

\section{Keywords:}

C\&DW

Recycled aggregates

Impurities

HPC

Geopolymers

\begin{abstract}
A B S T R A C T
The $70 \%$ minimum construction and demolition wastes-C\&DW recycling rate set by the Revised Waste framework Directive No. 2008/98/EC to be enforced beyond 2020, will increase the need of effective recycling methods in a dramatic manner. So far, recycled aggregates (which constitute the majority of C\&DW) are reused in low volume percentages for average compressive strength concretes and mostly as road sub-base and back-fill material which, in turn, constitutes a down-cycling option. Most investigations related to concrete made with recycled aggregates use aggregates produced in laboratory context which are not contaminated at all. It is then no surprise to find out that some investigations shows the potential to reuse as much as $100 \%$, however, industrially produced recycled aggregates contain a certain level of impurities that can be deleterious for Portland cement concrete, thus making very difficult for the concrete industry to use such investigations unless uncontaminated recycled aggregates are used. This paper reviews current knowledge on concrete made with recycled aggregates, with a special focus on the crucial importance of impurities presence and how those aggregates are not suitable for the production of HPC. Also, the potential of geopolymers to produce HPC based on high volume recycled aggregates is discussed.
\end{abstract}

(c) 2012 Elsevier Ltd. All rights reserved.

\section{Introduction}

The high volume of C\&DW generated nowadays constitutes a serious problem to be dealt with. Eurostat mention a total of 970 million ton/year of C\&DW representing almost 2.0 ton/per capita, however, currently the average recycling rate of C\&DW for EU-27 is just $47 \%$ (Table 1). According to the Revised Waste framework Directive 2008/98/EC [2] the minimum recycling percentage of C\&DW by the year 2020 should be at least $70 \%$ by weight. This target and also the Communication "A resource efficient Europe" [3] shows the determination of the EU to emphasize the importance of recycling. Worldwide aggregates consumption is about 20,000 million tons/year and an annual growth rate of $4.7 \%$ is expected [4]. More

\footnotetext{
* Corresponding author.

E-mail address: torgal@civil.uminho.pt (F. Pacheco-Torgal).
}

than one third of this consumption is related to concrete production, being the most used construction material on Earth and presently reaching about $10 \mathrm{~km}^{3} /$ year (Gartner and Macphee, 2011) [5]. The environmental impacts of primary aggregates include non-renewable raw materials consumption, energy consumption and more importantly the reduction of the biodiversity at the extraction sites. Since the cost of aggregates is very dependent on the transport distances, this leads to extraction operations having to be near construction sites which in turn multiplies the number of quarries and their biodiversity impacts. The benefits of a proper C\&DW management are not solely environmental, as the recent report Strategic Analysis of the European Recycled Materials and Chemicals Market in Construction Industry [6] states, that the market for recycled construction materials generated revenues of $€ 744.1$ million in 2010 , and is estimated to reach $€ 1.3$ billion by 2016 . This is, however, a very low estimate because it does not account for the 100\% C\&DW 
reuse scenario. Although the use of recycled aggregates in concrete has been studied for almost 50 years [7], todaýs concrete structures are still made with primary aggregates. The reasons for that rely in their low cost, low deposition taxes for C\&DW and the lack of positive discrimination toward the use of recycled aggregates. Besides, the use of recycled aggregates concrete in high-grade applications is rarely reported because of its poorer compressive strength and high in mechanical behavior variability [8]. This low performance means less durable concrete structures which require frequent maintenance and conservation operations or even its entire replacement (associated with the consumption of more raw materials and energy). The importance of durability in the context of eco-efficiency of construction and building materials has been rightly put by Mora [9], when he stated that increasing concrete durability from 50 to 500 years would mean a reduction of its environmental impact by a factor of 10 . It is also worth noticing that according to Hegger et al. [10], the increase of compressive strength in concrete would mean a reduction in reinforced steel amount by as much as $50 \%$. These are crucial issues in the efficiency of the materials agenda $[7,11]$, highlighting the need for investigations that may allow for high mechanical strength and high durability concretes capable of reusing a high volume of recycled aggregates.

\section{Concrete with recycled aggregates: an overview}

\subsection{HPC trials}

Very few investigations related to the reuse of recycled aggregates were able to achieve a high performance both in terms of mechanical properties as well as greater resistance to chemical attack typical of HPC [12]. Ajdukiewicz and Kliszczewicz [13] obtained $80 \mathrm{MPa}$ compressive strength concretes, however, those authors used recycled aggregate from an original concrete of about $60 \mathrm{MPa}$. Since the possibility of recycled aggregates produced in recycled plants coming from $60 \mathrm{MPa}$ old concretes is almost zero this means that it is unlikely to expect that recycled aggregates HPC could be produced in this way. Other authors [14] also attempted (and failed) to produce such material, reporting a 28 days compressive strength around $30 \mathrm{MPa}$ (Fig. 1) and concluding that "It is suggested not to utilize recycled aggregate for high, concrete strength applications due to long-term durability problems".

\subsection{Other relevant mechanical strength and durability investigations}

Recent investigations using recycled aggregates produced in laboratory point out to the fact that the use of fine recycled aggregates must not exceed $30 \%$, otherwise the concrete performance could be at risk [15]. Etxeberria et al. [16] studied the performance of concrete with natural fine aggregates and different replacement percentages of coarse recycled aggregates referring that the use of a percentage of $25 \%$ is associated to a compressive strength of

Table 1

Recycling rates of C\&DW in Europe [1].

\begin{tabular}{ll}
\hline Countries & $\begin{array}{l}\text { Recycling } \\
\text { rates }\end{array}$ \\
\hline Belgium (flanders) & Over 90\% \\
Denmark, Estonia, Germany, Ireland and Netherlands & Over 70\% \\
Austria, Belgium, France, Lithuania, UK & $60-70 \%$ \\
Luxemburgo, Letónia, Eslovenia & $40-60 \%$ \\
Average recycling rate for EU-27 & $47 \%$ \\
Cyprus, Czech Republic, Finland, Greece, Hungary, Poland, & Below 40\% \\
$\quad$ Portugal and Spain & \\
Bulgaria, Italy, Malta, Romania, Slovakia and Sweden & No data \\
& available \\
\hline
\end{tabular}

almost $40 \mathrm{MPa}$. It is noteworthy that these authors used a Type I 52.5R cement which not cost-efficient and has a high amount of clinker. So it is not obvious that the environmental advantages associated to the use of recycled aggregates exceed those of using a high $\mathrm{CO}_{2}$ emissions cement. Corinaldesi and Moriconi [17] showed that it is possible to use $100 \%$ industrially produced recycled aggregates ( $70 \%$ old concrete, $27 \%$ bricks and tiles and $3 \%$ miscellaneous (asphalt, glass, wood, paper and other similar construction debris)) with a compressive strength of almost $45 \mathrm{MPa}$ as long as silica fume are used with a $\mathrm{W} / \mathrm{C}=0.4$. Those authors further mention that no organic or alkali-silica reactive materials were detected; concerning the amount of chlorides and sulfates, they were below $0.04 \%$ (by weight) and $0.15 \%$ (by weight), respectively. Xia et al. [18] reviews research concerning the mechanical property, durability, and the structural performance of recycled aggregate concrete that has been carried out in the past 15 years (19962011) in China concluding that mechanical performance as well as durability are lower when compared to those of conventional concrete. The poor performance of recycled aggregate concrete is associated with cracks and fissures, which were formed in recycled aggregate during processing, thereby rendering the aggregate having weaker and more susceptible to permeation, diffusion and absorption of fluids. These drawbacks limit the utilization of the recycled aggregate with higher percentages $(>30 \%)$ in structural concrete [19]. The use of SCM's is usually used to compensate the drawbacks associated to the use of recycled aggregates, however, permeability and sorptivity of the matrix increases and the ingress of atmospheric $\mathrm{CO}_{2}$ is facilitated leading to an increase in concrete carbonation [20].

\subsection{The problem of impurities in recycled aggregates}

The majority of investigations related to the reuse of C\&DW in concrete use noncontaminated aggregates produced in laboratory making results to be difficult to extrapolate when contaminated recycled aggregates from recycled plants are used. Even those recycled aggregates obtained from real wastes containing almost zero contamination have been previously submitted to specific treatments, these are costly and that increase the environmental impact of recycled aggregates. Current recycled aggregates have particles

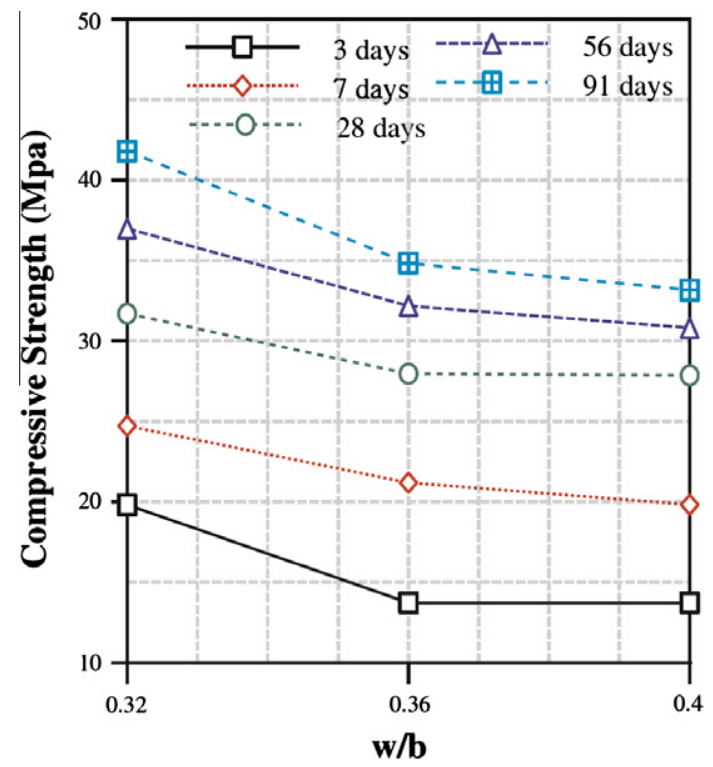

Fig. 1. The compressive strength of recycled aggregates HPC versus the age and the $\mathrm{w} / \mathrm{b}$ ratio [14]. 
of impurities such as soil, plastics, wastepaper, wood, metals and organic matter. Organic matter can delay Portland cement hydration thus leading to lower mechanical performance and lower concrete durability. The use of recycled aggregates contaminated with gypsum particles for concrete production is a risk factor for concrete durability. The deterioration of concrete is caused by the chemical reaction of sulfate ions with the alumina of the aggregates or with the tricalcium aluminate $\left(C_{3} A\right)$ of the hardened cement paste in the presence of water, both expansion products that can lead to the cracking of concrete. That is why the regulations on $\mathrm{C} \& \mathrm{DW}$ limited to less than $1 \%$ the presence of $\mathrm{SO}_{3}$. Aggregates that come from concrete structures affected by ASR or with a high chloride or sulfate content can also be considered to be containing some kind of impurities. Algarvio [21] studied a 50-80 ton/h C\&DW recycling plant noticing that contaminants percentage is very low with wood and metals being identified as the most frequent $(0.048 \%$ and $0.047 \%$ ). Agrela et al. [22] analyzed the physical and chemical characteristics of 35 mixed recycled aggregates which have been obtained from 11 different CDW treatment plants of Spain noticing that $25.7 \%$ of aggregates show $2 \%$ of gypsum. Other authors [23] also detected a high sulfate content of $1.52 \%$ that clearly exceeds the Spanish Structural Concrete Code EHE-08 upper limit of $0.80 \%$. Other authors [24] studied the performance of concrete with recycled aggregates contaminated by chlorides than sulfates stating that the contamination does not seem to influence the mechanical performance. However, they mention that concrete with contaminated recycled aggregates is much more prone to corrosion (Fig. 2). Those authors mention that precautions and specific measurements need to be taken, especially with aggregates from hazardous or critical origin such as sewage water plants, road infrastructures or buildings under marine environments. Park and Noguchi [25] studied concrete containing metal impurities with various size and content and it was found that aluminum, contained in recycled aggregate, caused performance degradation in both mechanical properties and durability of recycled aggregate concrete even with very low contents of less than $0.1 \%$ (Fig. 3 ). The chemical reaction between aluminum impurity and alkaline concrete can generate hydrogen gas which, in turn, is responsible for gas layer, foam, crack and rock pocket in hardened concrete. This leads to the significant degradation of mechanical properties of concrete which conduces to the need of more efficient screening methods that may increase the cost of recycled aggregates and reduce its environmental advantage.

\subsection{Recycled aggregate concrete standards}

Different countries have different standards related to the production of recycled aggregate concrete. In Portugal the standard LNEC E 471 [26] puts into practice the content of the Directive EN 12620:2002 [27]. According to the LNEC E 471 C40/50 is the maximum compressive strength class allowed for structural concrete made with recycled aggregates. This standard limits to $25 \%$ the volume of recycled aggregates for the C40/50 strength class,

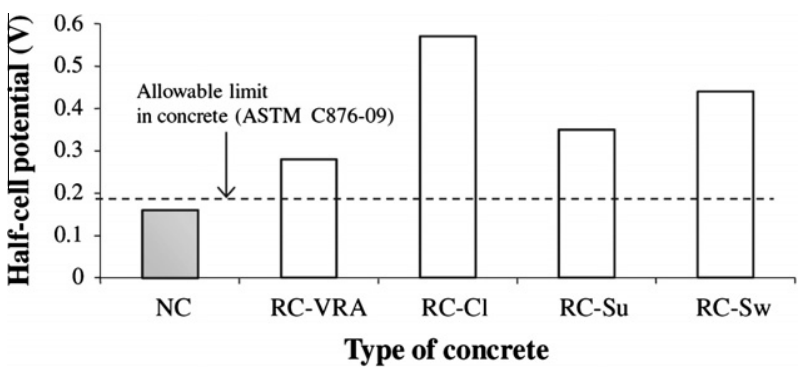

Fig. 2. Half-cell potential of recycled reinforced concrete beams [24].

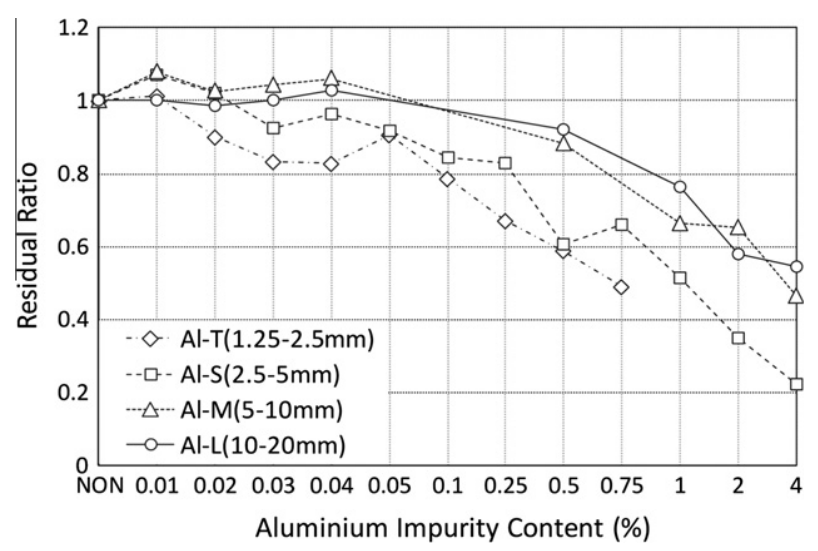

Fig. 3. Relationship between aluminum impurity content and residual ratio of compressive strength [25].

requires that concrete and stone aggregates should be at least $90 \%$ and sets upper limits for the impurity content. Glass and other undesirable particles cannot exceed $0.2 \%$. Other standards also set limits on the impurity content (Table 2). The existent standards on this field also make the evaluation of ASR contamination mandatory as well as leaching tests, however, this prerequisites represent a cost that will reduce the attractiveness of concrete made with recycled aggregates.

\section{Geopolymers potential for reusing recycled aggregates in HPC}

So far investigations related to the geopolymerization of C\&DW are scarce [31,32], nevertheless, it seems that this binder has potential features to reuse recycled aggregates for the production of HPC. For the same water/binder ratio several authors reported that geopolymers present a higher mechanical strength than Portland cement. Wang [33] states a case of a geopolymeric concrete with $125 \mathrm{MPa}$ compression strength. Other authors [34] declare having obtained a $20 \mathrm{MPa}$ strength just after $4 \mathrm{~h}$ increasing to 70-100 MPa after 28 days curing. Fernandez-Jimenez et al. [35] studied mortars $(\mathrm{w} / \mathrm{b}=0,51)$ activated with $\mathrm{NaOH}$ and waterglass reporting $100 \mathrm{MPa}$ for compressive strength. Fernandez-Jimenez and Palomo [36] used slag/fly ashes mixtures activated with $\mathrm{NaOH}$ and waterglass $(\mathrm{w} / \mathrm{b}=0,35)$ announcing a $90 \mathrm{MPa}$ compressive strength just after $20 \mathrm{~h}$. Bakharev [37] studied fly ash pastes activated with $\mathrm{NaOH}$ and waterglass $(\mathrm{w} / \mathrm{b}=0,3)$ stating a $60 \mathrm{MPa}$ compressive strength just after 2 days. Other authors [38,39] report a compressive strength higher than $30 \mathrm{MPa}$ after only one day, reaching almost $70 \mathrm{MPa}$ after 28 days curing and $90 \mathrm{MPa}$ at 90 days curing. In conventional concrete, the aggregates form a rigid skeleton of granular elements which are responsible for compressive strength, in geopolymers most of the compressive strength is related to the matrix characteristics, therefore, this material does not rely in well-proportioned aggregate mixtures. This makes geopolymer concrete more suitable to reuse recycled aggregates. Concerning the resistance to acid attack, geopolymer performance is far better than that of Portland cement concretes because it does not contain $\mathrm{Ca}(\mathrm{OH}) 2$, a soluble hydration product that constitutes the "Achilles' heel" of Portland cement concrete. Davidovits et al. [40] reported mass losses of $6 \%$ and $7 \%$ for geopolymeric binders immersed in $5 \%$ concentration hydrochloric and sulfuric acids during 4 weeks. For the same conditions he also observed that Portland cement based concretes suffered mass losses between 78\% and 95\%. Other authors [41] mentioned that a Portland cement concrete with a service life of 50 years lost $25 \%$ of its mass after 80 immersions cycles in a sulfuric acid solution $(\mathrm{pH}=1)$ while a geopolymeric concrete required 1400 immersions cycles to lose the same mass, thus meaning a service life of 
Table 2

Impurity content in the Japanese, British and Korean standards [28-30].

\begin{tabular}{|c|c|c|c|}
\hline Standard & Contents of impurities & & Limit by mass fraction (\%) \\
\hline \multirow[t]{7}{*}{ J1S A 5021 (Japan) } & A & Tile. brick, ceramics, asphalt concrete lump & 2.0 \\
\hline & B & Glass piece & 0.5 \\
\hline & $\mathrm{C}$ & Gypsum, plasterboard piece & 0.1 \\
\hline & $\mathrm{D}$ & Inorganic board & 0.5 \\
\hline & E & Plastic piece & 0.5 \\
\hline & $\mathrm{F}$ & Wood, wastepaper, asphalt lump & 0.1 \\
\hline & Limit of total amount & & 3.0 \\
\hline \multirow[t]{5}{*}{ BS $8500-2$ (UK) } & Maximum masonry content & & 5.0 \\
\hline & Maximum fines & & 5.0 \\
\hline & Maximum lightweight material & & 0.5 \\
\hline & Maximum asphalt & & 0.5 \\
\hline & Maximum other foreign material, e.g. glass, plastics, metals & & 1.0 \\
\hline \multirow[t]{2}{*}{ KS F 257b (Korea) } & Wood, wastepaper, plastic piece, etc. (volume fraction (\%)) & & 1.0 \\
\hline & Tile, brick, ceramics, asphalt concrete lump, etc. & & 1.0 \\
\hline
\end{tabular}

900 years. More recently Pacheco-Torgal et al. [42] mentioned an average mass loss of just $2.6 \%$ after being submitted to the attack of (sulfuric, hydrochloric and nitric) acids during 28 days, while the mass loss for Portland cement concretes is more than twice that value. Geopolymers are also less [43] susceptible to generate expansion by alkali-silica reaction than OPC and show excellent freeze-thaw resistance [44]. These materials have another advantage over Portland cement concrete that is particularly interesting in the case of reusing contaminated recycled aggregates, a high immobilization capacity. According to Hermann et al. [45] the use of alkali-activated binders is a good way to immobilize a wide range of harmful constituents such as toxic metals, hydrocarbonates and even nuclear wastes in a final product with high durability and costing much less than the current vitrification process. Vinsova et al. [46] refer that alkali-activated binders show a good performance in the immobilization of lead, cadmium and chromium, being less effective for immobilization of arsenic. Lancellotti et al. $[47,48]$ showed that metakaolin based geopolymers binders are able to immobilize toxic metals present in fly ash due to the incineration of municipal solid wastes. Immobilization of a municipal solid waste incineration residue using geopolymers was recently reported [49]. Other authors [42,50] showed that geopolymeric binders can be used for the reuse of mine wastes. Besides geopolymeric concretes are associated to lower $\mathrm{CO} 2$ emissions than Portland cement concretes [51-53]. This is a crucial advantage because Portland cement, represents almost $80 \%$ of the total $\mathrm{CO} 2$ emissions of concrete which in turn are about $6-7 \%$ of the Planet's total $\mathrm{CO} 2$ emissions [54,55]. Nevertheless, geopolymers suffer from severe efflorescence [56], because the bond between the sodium ions $(\mathrm{Na}+)$ and the aluminosilicate structure is weak which explains the leaching behavior $[57,58]$. According to those authors it is the presence of water that weakens the bond of sodium in the aluminosilicate polymers, a behavior that is confirmed by the geopolymer structure model (Fig. 4). However, other authors [59] mention that efflorescences do not occur when geopolymers are cured at elevated temperature which means the leachate sodium could be a sign of insufficient geopolymerisation, thus meaning that further investigations are needed to solve this issue.

\section{Conclusions}

The 970 million ton/year of C\&DW generated nowadays in Europe constitutes a serious problem to be deal with. Currently the average recycling rate of C\&DW for EU-27 is just 47\%, however, the Revised Waste framework Directive No. 2008/98/EC sets the minimum recycling percentage for C\&DW at least $70 \%$ by weight until the year 2020. This highlights the need of investigations that allow for high mechanical strength, high durability concretes capable of reusing a high volume of recycled aggregates. Very few

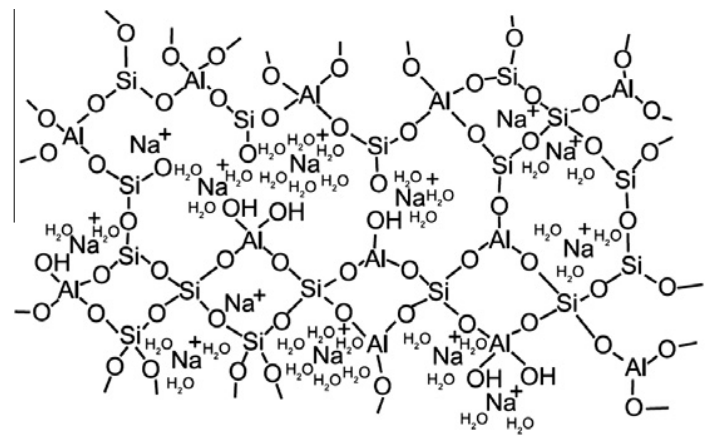

Fig. 4. Geopolymer structure model [58].

investigations related to the reuse of recycled aggregates were able to achieve a high performance both in terms of mechanical properties as well as greater resistance to chemical attack typical of HPC. Poor performance of the recycled aggregate concrete is associated with the cracks and fissures, which were formed in recycled aggregate during processing, thereby rendering the aggregate having weaker and more susceptible to permeation, diffusion and absorption of fluids. These drawbacks limit the utilization of the recycled aggregate with higher percentages $(>30 \%)$ in structural concrete. Besides most investigations on recycled aggregate concrete use a Type I cement, that has a high clinker content so it is not obvious that the environmental advantages associated to use of recycled aggregates exceed those of using a high $\mathrm{CO}_{2}$ emissions cement. Industrially produced recycled aggregates are usually contaminated by gypsum particles, ASR contaminated concrete aggregates or even by other contaminants thus reducing its reuse by Portland cement concrete. Geopolymers seems to have the potential to produce HPC based on high volume recycled aggregates. They can achieve a very high compressive strength just after one or two days, allowing for shorter concrete structures execution. They also have a high resistance to acid attack and a remarkable capacity to immobilize harmful constituents which is a crucial feature when contaminated recycled aggregates were used.

\section{References}

[1] Sonigo P, Hestin M, Mimid S. Management of construction and demolition waste in Europe. Stakeholders Workshop, Brussels; 2010.

[2] European Parliament, directive 2008/98/EC of the European Parliament and of the council of 19 November 2008 on waste and repealing certain directives (text with EEA relevance). Official Journal of the European Union. 312: p. 3-30.

[3] COM (2011) 21: A resource-efficient Europe - flagship initiative under the Europe 2020 strategy; Brussels.

[4] Bleischwitz R, Bahn-Walkowiak B. Aggregates and construction markets in Europe: towards a sectorial action plan on sustainable resource management. Miner Eng 2011;22:159-76. 
[5] Gartner E, Macphee D. A physico-chemical basis for novel cementitious binders. Cem Concr Res 2011;41:736-49.

[6] Strategic analysis of the European recycled materials and chemicals market. Frost \& Sullivan. < http://www.frost.com/prod/servlet/report-toc.pag?repid =M579-01-00-00-00>

[7] Pacheco-Torgal F, Jalali S. Eco-efficient construction and building materials. London (UK): Springer Verlag; 2011.

[8] Tam V, Gao X, Tam C. Microstructural analysis of recycled aggregate concrete produced from two-stage mixing approach. Cem Concr Res 2005;35:1195-203.

[9] Mora E. Life cycle, sustainability and the transcendent quality of building materials. Build Environ 2007;42:1329-34.

[10] Hegger J, Nitsch A, Burkhardt J. Hchleistungbeton im Fertigteilbau. Betonwerk Fertigteil - Technik 1997;2:81-90.

[11] Allwood J, Ashby M, Gutowski T, Worrell E. Material efficiency: a white paper. Resour Conserv Recycl 2011;55:362-81.

[12] Aitcin P. The durability characteristics of high performance concrete: a review. Cem Concr Compos 2003;25:409-20.

[13] Ajdukiewicz A, Kliszczewicz A. Influence of recycled aggregates on mechanical properties of HS/HPC. Cem Concr Compos 2002;24:269-79.

[14] Tu T-Y, Chen Y-Y, Hwang C-L. Properties of HPC with recycled aggregates. Cem Concr Res 2006;36:943-50.

[15] Evangelista L, Brito J. Mechanical behaviour of concrete made with fine recycled concrete aggregates. Cem Concr Compos 2007;29:397-401.

[16] Etxeberria M, Mari A, Vazquez E. Recycled aggregate concrete as structural material. Mater Struct 2007;40:529-41.

[17] Corinaldesi V, Moriconi G. Influence of mineral additions on the performance of 100\% recycled aggregate concrete. Constr Build Mater 2009;23:2869-76.

[18] Xia J, Li W, Fan Y, Huang X. An overview of study on recycled aggregate concrete in China (1996-2011). Constr Build Mater 2012;31:364-83.

[19] Kou S, Poon C. Enhancing the durability properties of concrete prepared with coarse recycled aggregate. Constr Build Mater 2012;35:69-76.

[20] Pacheco-Torgal F, Miraldo S, Labrincha J, De Brito J. An overview on concrete carbonation in the context of eco-efficient construction: measurement, use of SCM's and/or RCA. Construction and Building Materials 2012;36:141-50.

[21] Algarvio D. Recycling of C\&DW: a contribution for process improvement. Master thesis. FCT/UNL, Lisbon; 2009 [in Portuguese].

[22] Agrela F, Sánchez de Juan M, Ayuso J, Geraldes VL, Jiménez JR. Limiting properties in the characterization of mixed recycled aggregates for use in the manufacture of concrete. Constr Build Mater 2011;25:3950-5.

[23] Martin-Morales M, Zamorano M, Ruiz-Moyano A, Valverde-Espinosa I. Characterization of recycled aggregates construction and demolition waste for concrete production following the Spanish structural concrete code EHE08. Constr Build Mater 2011;25:742-8.

[24] Debieb F, Courard L, Degeimbre R. Mechanical and durability properties of concrete using contaminated recycled aggregates. Cement and Concrete Composites 2010;32:421-6.

[25] Park W, Noguchi T. Influence of metal impurity on recycled aggregate concrete and inspection method for aluminum impurity. Construction and Building Materials (in press).

[26] LNEC E 471: 2006. Guide for the use of coarse recycled aggregates in concrete.

[27] EN 12620:2002. Aggregates for concrete.

[28] Japan industrial standard. Recycled concrete for concrete-class H. JIS A 5021; 2007. p. 101.

[29] British standard. Specification for constituent materials and concrete. BS 8500. 2002; $2: 7-8$

[30] Korea standard. Testing method for impurity contents of recycled aggregate. KS F 2576; 2006. p. 1-7.

[31] Lampris C, Lupo R, Cheeseman C. Geopolymerization of silt generated from construction and demolition waste washing plants. Waste Manage 2009;29:368-73.

[32] Allahverdi A, Najafi Kani E. Construction wastes as raw materials for geopolymer binders. Int J Civ Eng 2009;7:154-60.

[33] Wang S. Review of recent research on alkali-activated concrete in china. Mag Concr Res 1991;5154(1991):29-35.

[34] Davidovits J. Properties of geopolymers cements. In: Proc of the 1st international conference on alkaline cements and concretes. Ukraine: Scientific Research Institute on Binders and Materials Kiev; 1994. p. 131-49.

[35] Fernandez-Jimenez A, Palomo J, Puertas F. Alkali activated slag mortars. Mechanical strength behaviour. Cem Concr Res 1999;29:1313-21.
[36] Fernandez-Jimenez A, Palomo A. Composition and microstructure of alkali activated fly ash binder: effect of the activator. Cem Concr Res 2005;35:1984-92

[37] Bakharev T. Geopolymeric materials prepared using class F fly ash and elevated temperature curing. Cem Concr Res 2005;35:1224-32.

[38] Pacheco-Torgal F, Gomes JP, Jalali S. Investigations about the effect of aggregates on strength and microstructure of geopolymeric mine waste mud binders. Cem Concr Res 2007;37:933-41.

[39] Pacheco Torgal F, Gomes JP, Jalali S. Investigations on mix design of tungsten mine waste geopolymeric binders. Constr Build Mater 2008;22: 1939-49.

[40] Davidovits J, Comrie DC, Paterson JH, Ritcey DJ. Geopolymeric concretes for environmental protection. ACI Concr Int 1990;12:30-40.

[41] Gourley JT, Johnson GB. Evelopments in geopolymer precast concrete. In: Quentin S, editor. Proc of geopolymer 2005 world congress. France: Geopolymer Green Chemistry and Sustainable Development Solutions; 2005. p. $139-43$.

[42] Pacheco-Torgal F, Gomes J, Jalali S. Durability and environmental performance of alkali-activated tungsten mine waste mud mortars. J Mater Civ Eng 2010;22:897-904.

[43] García-Lodeiro I, Palomo A, Fernández-Jiménez A. Alkali - aggregate reaction in activated fly ash systems. Cem Concr Res 2007;37(2007):175-83.

[44] Fu Y, Cai L, Wu Y. Freeze-thaw cycle test and damage mechanics models of alkali-activated slag concrete. Constr Build Mater 2011;25:3144-8.

[45] Hermann E, Kunze C, Gatzweiler R, Kiebig G, Davidovits J. Solidification of various radioactive residues by geopolymer with special emphasis on long term stability. In: Proc of 1999 geopolymere conference; 1999. p. 211-28.

[46] Vinsova H, Jedinakova-Krizova, Gric L, Sussmilch J. Immobilization of toxic contaminants into aluminosilicate matrixes. In: Proceedings of the 2007 alkali activated materials - research, production and utilization 3rd conference. Prague: Czech Republic; 2007. p. 735-6.

[47] Lancellotti, et al. Show that alkali-activated metakaolin binders are able to immobilize toxic metals present in fly ash due to the incineration of municipal solid wastes; 2010.

[48] Lancellotti I, Kamseu E, Michelazzi M, Barbieri L, Corradi A, Leonelli C. Chemical stability of geopolymers containing municipal solid waste incinerator fly ash. Waste Manage 2010;30:673-9.

[49] Galiano Y, Pereira C, Vale J. Stabilization/solidification of a municipal solid waste incineration residue using fly ash-based geopolymers. J Hazard Mater 2011;185(2011):373-81.

[50] Zhang L, Ahmari S, Zhang J. Synthesis and characterization of fly ash modified mine tailings-based geopolymers. Constr Build Mater 2011;25:3773-81.

[51] Duxson P, Provis J, Luckey G, Van Deventer J. The role of inorganic polymer technology in the development of "green concrete". Cem Concr Res 2007;37:1590-7.

[52] Weil M, Dombrowski K, Buchawald A. Life-cycle analysis of geopolymers. In: Provis J, Van Deventer J, editors. Geopolymers, structure, processing properties and applications, ISBN-13: 978184569449 4. Cambridge (UK): WoodHead Publishing Limited Abington Hall; 2009. p. 194-210.

[53] Habert G, de Lacaillerie J, Roussel N. An environmental evaluation of geopolymer based concrete production: reviewing current research trends. J Cleaner Prod 2011;11:1229-38.

[54] Shi C, Fernández Jiménez A, Palomo A. New cements for the 21st century: the pursuit of an alternative to Portland cement. Cem Concr Res 2011;41:750-63.

[55] Pacheco-Torgal F, Jalali S, Labrincha J, John V. Eco-efficient concrete. Cambridge (UK): WoodHead Publishing Ltd.; 2012. in press.

[56] Pacheco Torgal F, Jalali S. Influence of sodium carbonate addition on the thermal reactivity of tungsten mine waste mud based binders. Constr Build Mater 2010;24:56-60

[57] Skvara F, Kopecky L, Smilauer V, Alberovska L, Bittner Z. Material and structural characterization of alkali activated low-calcium brown coal fly ash. J Hazard Mater 2008:168:711-20.

[58] Skvara F, Kopecky L, Smilauer V, Alberovska L, Vinsova L. Aluminosilicate polymers - influence of elevated temperatures, efflorescence. Ceram - Silikaty 2009;53:276-82.

[59] Temuujin J, Van Riessen A, Williams R. Influence of calcium compounds on the mechanical properties of fly ash geopolymer pastes. J Hazard Mater 2009;167:82-8. 